サンフランシスコ市・ロサンゼルス市における環境情報の公開・共有をふまえた 環境レヴューの建築計画・設計に対する適用の特徵

\title{
CHARACTERISTICS OF ENVIRONMENTAL REVIEWS WITH DISCLOSURE PROCESS FOR ARCHITECTURAL PLANNING AND DESIGN AT CITY OF SAN FRANCISCO AND CITY OF LOS ANGELES
}

\author{
田川正毅*, 眞嶋二郎**, 野口孝博*** \\ Seiki TAGAWA, Jiro MAJIMA and Takahiro NOGUCHI
}

\begin{abstract}
This study analyzes usage and applications based upon environmental reviews of the California Environmental Quality Act; Regarding the various architectural projects at City of San Francisco and City of Los Angeles. Architectural sites issues, contexts and city identity which are reflected through the environmental reviews are essentially important for architectural planning and design. Especially, considerations for cultural and historical resources are important in both cities. In addition, the disclosure process of environmental reviews encourages the public participation from the early design phase. Therefore, the environmental reviews make the importance of the early design phase clear among all the project design procedure, and contribute awareness of architectures regarding surrounding environmental issues.
\end{abstract}

\section{Keywords : Environmental Review, Environmental Impact Report, Historical and Cultural Resources, Disclosure Process, Public Participation 環境レヴュー、噮境影響評価、歷史的・文化的資源、情報公開プロセス、市民参加}

\section{1. 研究の目的と祖い}

本論ではカリフォルニア州の 2 大都市圈の中心都市、サンフラン シスコ市とロサンゼルス市の多様な建築に対する環境レヴュー注 1) の適用事例の分析から、そこでの環境レヴューが建築計画・設計に 対してどのような役割と特徴を持ち適用されているのかを明らかに することを目的とする。

筆者らは既往研究文1) 文2)において、30 年以上にわたり環境情報 の公開・共有を前提とした環境レヴューを積み重ねてきた米国・カリ フォルニア環境質法 (CEQA: California Environmental Quality Act, Public Resources Code §21000 et seq.) 文3)を取り上げ、最 初にその成熟過程が顕著に表れる判例の分析から、建築計画・設計 と関る環境レヴューの全体構造的な意味を明らかにした文1。次に大 学キャンパス施設計画に適用された環境レヴューの分析から、建築 計画・設計プロセスにおける環境レヴューの具体的な役割と有効な 活用方法を示した文2)。本論では都市部での多様な種類の建築に対す る環境レヴューの適用実態の分析を行い、建策と環境レヴューの関 りを都市的な背景や両市の担当部局の運用方針もふまえて考察する。 CEQA の環境レヴューは日本での地方自治体の環境アセスメント に相当するが、日本の場合は大規模事業や特定地域の事業が主な対
象である注 2)。これに対して CEQA は公的機関が裁量を有して関る 行為(Discretionary Project) 注3) の全般を対象とする。適用除外行 為注4) はあるが、総合計画(General Plan)・特定計画(Specific Plan) 等の都市・地区レベルの計画から、都市再開発・宅地開発などの開 発事業、さらに単体の建築を含む公共及び民間の多様な事業を対象 に、環境面から計画の情報公開を図る基礎的な仕組み文 3)である。 本研究ではカリフォルニア州の都市建築の環境影響報告書 (EIR : Environmental Impact Report）を分析することで、日本の場合と の建築計画・設計に対する意味の相違を明確にし、建築計画・設計 の質の向上に役立てることを狙っている。

\section{2. 研究の対象と方法}

サンフランシスコ市とロサンゼルス市はカリフォルニア州の 2 大 都市圈の中心都市で、前者は公共交通が発達し歷史的な街並みを多 く残す都市であるのに対し、後者は自家用車への依存度が高く郊外 スプロールが過度に進行するなど対照的な特徴を持ち、都市的な背 景をふまえた比較検討に適していることから調查対象とした。

CEQA の環境レヴューには 3 種類の申告書注5) があるが EIR は最 も詳細な影響評価を伴い、市民の意見表明や担当部局の運用意図も 顕著に表れることから本研究の検討対象とした。CEQAの対象行為
北海道東海大学芸術工学部くらしデザイン学科 助教授・博士 (工学)

** 北海道大学大学院工学研究科都市環境工学尃攻 教授. 工博

*** 北海道大学大学院工学研究科都市環境工学専攻 Assoc. Prof., Dept. of Design and Architecture, Faculty of Art and Technology,
Hokkaido Tokai University, Dr. Eng.

Prof., Division of Urban Environmental Engineering, Graduate School of Engineering, Hokkaido University, Dr. Eng.

Assoc. Prof., Division of Urban Environmental Engineering, Graduate School of Engineering, Hokkaido University, Dr. Eng. 
表- 1 調查対象の EIR

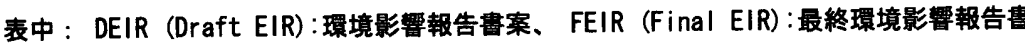

\begin{tabular}{|c|c|c|c|c|c|c|c|c|c|c|c|c|c|}
\hline & & & & & & & & & 歴史 & !的-文化的 & 資源との関 & & \\
\hline 市 & $\begin{array}{l}\text { 事例 } \\
\text { 番号 }\end{array}$ & 建物種別 & 事莱主体 & DEIR 提出 & FEIR 承認 & 面積 $\left(\mathrm{m}^{2}\right)$ & 階 & $\begin{array}{l}\text { 敷地内資源 } \\
\text { の保全 }\end{array}$ & $\begin{array}{l}\text { 敷地内資源 } \\
\text { の解体 }\end{array}$ & 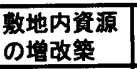 & 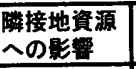 & $\begin{array}{l}\text { 歴史的地区 } \\
\text { への影警 }\end{array}$ & 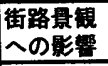 \\
\hline & $\mathrm{SF}-1$ & 教会の付属施設 & 教会 & 1992.7. & 1993.2 & 3,437 & 3 & 0 & & & & & \\
\hline & $\mathrm{SF}-2$ & 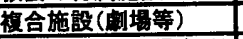 & 底間 & 1996.3 & 1996.5 & 39.455 & 8 & & & 0 & & & \\
\hline サ & $\mathrm{SF}-3$ & 集合住宅(低所得向(t) & 底間 & 1996.9. & 1996.12 & 6.400 & 15 & & o & & & & \\
\hline ント & $\mathrm{SF}-4$ & 呼児施殷 & 民闌 & 1998.4 . & 1999.5 & 1,008 & 2 & & o & & & & \\
\hline & $S F-5$ & 整務所施設 & 間 & 1997.7. & 1998.2 & 5,900 & 4 & & & O & & & \\
\hline$=$ & $\mathrm{SF}-6$ & 物販施謗 & 間間 & 1998.1. & 2000.1 & 84,632 & $17 \mid$ & & & 으 & & & \\
\hline ラ & $\mathrm{SF}-7$ & 集合住宅(分䫱) & 民間 & 1998.7 & 2000.8 & 548 & 6 & & & & & 0 & $\bar{O}$ \\
\hline ン & $\longdiv { S F - 8 }$ & 集合住宅(賽費) & 民間 & 1999.1 & 1999.7 & 8,820 & 4 & & O & & & & \\
\hline シ & $S F-9$ & 慗務所施般 & 民間 & 1999.11 & 2000.3 & 15,550 & 4 & & 0 & & & & \\
\hline z & $S F-10$ & 車務所施設 & 民間 & 1999.7. & 2000.1 & 109,250 & 9 & & & $\overline{0}$ & & & \\
\hline ㄴ. & $\mathrm{SF}-11$ & 木テル+交通施殿 & 公共十民間 & 1999.8 & 2000.1 & 12.727 & 8 & & & & O & & \\
\hline コ & $\mathrm{SF}-12$ & 㫿務所施設 & 民間 & 2000.6 & 2000.7 & 29,170 & 4 & & & & & & \\
\hline 市 & $\mathrm{SF}-13$ & 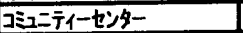 & 民間 & 2000.8 & 2000.9 & 11.670 & 3 & & O & & & & \\
\hline & SF-14 & 美街館 & 民間期团 & 2000.7 & 2000.11 & 2.787 & 2 & & & & & & \\
\hline & SF-15 & 莗務所施設 & 民間 & 2001.5 & 2001.9 & 3,650 & 8 & & & & & & 0 \\
\hline & LA-1 & 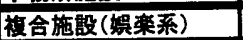 & 民間 & 1991.1 & 1993.3 & 71,916 & 20 & 0 & & & & & \\
\hline & LA-2 & 複合施設(ホテル等) & 民間 & 1991.1 & 1992.1 & 44,083 & 5 & O & & & & & \\
\hline & LA-3 & 策務所施設 & 民間 & 1992.1 & 1992.8 & 111,480 & 30 & & & & & & O \\
\hline 口 & LA-4 & 複合施設(物販系) & 民間 & 1992.12 & 1993.3 & 54,575 & 25 & & & & & 5 & \\
\hline+ & LA-5 & 简等学校 & 私立学校 & 1992.9 & 1993.2 & 7.627 & 3 & & & & & & \\
\hline 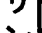 & LA-6 & 陑院 & 民間 & 1993.4 & 1993.9 & 6,147 & 4 & & & & & & \\
\hline ン & LA-7 & 大学 & 私立学校 & 1995.8 & 1998.2 & 5,147 & 4 & & & & & o & \\
\hline ゼ & LA-8 & 複合施設(物販系) & 民間 & 1997.4 & 1997.11 & 34,437 & 3 & & & & & & \\
\hline ル & LA-9 & スポーツ施設 & 民間 & 1997.3 & 1997.7 & 83,610 & 5 & & & & 0 & & \\
\hline & $L A-10$ & 娮俬施設 & 民間 & 1997.11 & 1998.3 & 111,480 & 24 & & & & & 0 & 으 \\
\hline 조 & LA-11 & 席院+集合住宅 & 䈨間 & 2000.9 & 2001.12 & 51,891 & 3 & & & & & & \\
\hline 市 & LA-12 & 複合施設 (飲食系) & 房間 & 2001.6 & 2001.9 & 5.082 & $\frac{3}{3}$ & & & & & & \\
\hline & LA-13 & 中学校 & 私立学校 & 2001.6 & 2001.11 & 6.989 & 3 & & 0 & & & & \\
\hline & $L A-14$ & 澓合施設(文化施設等) & 民間 & 2002.8 & 2002.1 & 72,364 & 15 & & & & & & \\
\hline & LA-15 & 集合住宅 & 民間 & 2002.9 & 2003.2 & 49.097 & 5 & & & & & & \\
\hline
\end{tabular}

は広く、担当部局である両市の計画局(Planning Department)、ま た州政府の OPR(Office of Planning and Research) も適用行為の 種別による分類はしていない。本研究では環境レヴューと建築の関 りを考察することから、申告書を閲覧できる両市の中央図書館で建 築関連のキーワードを用いて 1990 年以降のものを検索し、できる だけ多くの建築種別を含むように両市各 15 の EIR を抽出した注6)。 それらの概要を表-1 に示す (以降の文中及び表の事例番号は表-1に 示す)。さらに両市の担当部局に対し聴取調查を行い注7)、CEQAの 運用意図とそこでの課題の認識について考察した。EIR の分析にあ たっては、最初にそこに含まれる検討項目を比較することで両市の EIR の傾向を捉えた。次に、そこで見出された特徴的な EIRについ て詳細に検討した。特に、論争になった事例は環境レヴューの役割 と課題が表れると考えられることから、EIR の付帯資料と担当部局 に対する聴取調査を含めて計画の背景を含めた考察を行った。

\section{3. 既往研究との関係}

CEQA に関して、(財) 地球・人間環境フォーラムは「世界の環境 アセスメント」文 4) の中で、米国の州レベルの代表的な環境影響評 価制度として CEQA の概要を紹介している。日本都市計画学会では 秋本丈 ${ }^{5)}$ が、カリフォルニア州における公共と民間の協議による都 市開発の制度的な枠組みは、(1)計画・ゾーニング法(The Planning and Zoning Law)、(2)コミュニティー再開発法(The Community Redevelopment Law)、(3)CEQA の 3 つであり、CEQA の制定が地 方自治体とデベロッパーによるコミュニティーとの協議を大きく促 進したこと、また計画プロセスと環境審査のプロセスが統合されて いることの重要性を指摘している。またウィリアム・フルトン文6) はカリフォルニア州の都市計画の解説の中で、CEQAによって諸計
画の手続きの中に情報公開と市民参加が図られてきた経緯を解説し ている。西村ら文 7はアバンデザインと歴史的環境保全の視点か らサンフランシスコ市の都市計画と景観コントロール施策を解説し ている。しかし日本での既往研究や文献は、建築計画・設計と環境 レヴューの関係性についての検討は十分には行われていない。 CEQA は多様な裁量行為を対象とし、CEQA の主要な解説書文8)·文9) でも建築に対する具体的な適用実態の説明は見られない。米国の CEQA に関する主要な既往調查文 10)文11) 女12)からは、その有効性と問 題点の全体傾向を知ることができるが、建築との関係や計画・設計 への影響については分からない。米国の環境影響評価についての研 究誌文 13)文 14)では、都市開発との関連の研究は見られるものの建築計 画・設計の視点から考察したものは見られなかった。

本論は筆者らの既往研究 (文 1-文2)を踏まえ、CEQA の環境レヴ ューが建築にどのように適用されるかの考察を通して、環境レヴュ 一が建筮計画・設計プロセスにおいて持つ役割と意義を明らかにす るところに特徴がある。

\section{4. 両市のEIRから見た環境レヴューの適用の特徵 \\ 4-1. EIR の図面等の内容から見た特徵}

CEQA のガイドラインでは、「環境レヴューを適正な評価が可能 な範囲内で計画のできるだけ早期に実施する」ことを求めている。 建筑計画・設計プロセスのどの段階で行なわれているのかを知るた めに、EIRの図面等の内容を比較したものを表-2に示す。

両市とも配置図・平面図・立面図と高さや規模の情報を基本に、 外観イメージを示寸資料を加えている。そこでの外観は街路景観に 建物ボリュームを線画で示した程度のものから、手書きのスケッチ、 C Gによるモンタージュ写真まで様々である。また外壁材料等の詳 
細は、サンフランシスコ市中心部で外観デザインが特に論議を呼ん だ SF-15 の事例を除き含まれていない。こうした簡易な内容は米国 における基本計画段階(Schematic Design Phase)の図面程度であり、 何もしない場合(No Project)や代替敷地の代案評価も行われている こと、また担当部局への聴取調查から、CEQA の環境レヴューは詳 細設計に進む前の建築計画・設計の初期段階の計画内容に対して行 われることが分かる(図-8 参照)。

\section{表-2ＥIRに含まれる図面等の内容}

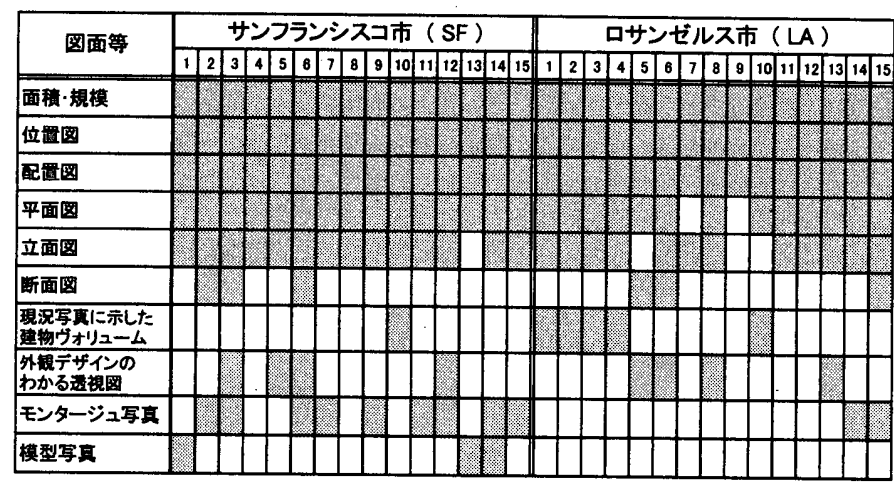

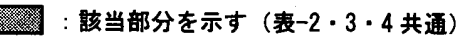

\section{4-2. EIRの環境影㬝評価項目から見た特徵}

次に EIR の環境影響評価項目を比較する。表-3 の左欄は CEQA のガイドラインによる標準評価項目であるが、両市の担当部局は環 境レヴューの作成及び審查を担当する主導機関（Lead Agency）と して、申告書作成前の淮備検討(Initial Study)で評価項目の絞り込み (Scoping)を行い EIR を作成している。サンフランシスコ市の EIR の評価項目数の平均が 6.4 であるのに対し、ロサンゼルス市での平 均は 12.3 と多い。その理由は、サンフランシスコ市の場合は評価項 目を建築毎に特に顕著な環境影響項目に絞り込んでいるためである。

\section{表-3ＥIR の環境影響評価項目}

\begin{tabular}{|c|c|c|c|c|c|c|c|c|c|c|}
\hline & 鲆価項目 & サン & フランシ & ルコ市 & (SF) & & ロサ & ナンゼルン & ス市（L & LA ) \\
\hline & 旪地買日 & 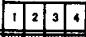 & \begin{tabular}{|l|l|l|l}
5 & 8 & 7 & 8 \\
\end{tabular} & \begin{tabular}{|l|l|l|}
8 & 0 & 10 \\
\end{tabular} & $12 \sqrt[13]{16}$ & 19. 15.1 & 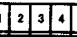 & \begin{tabular}{|l|l|l|l|}
5 & 6 & 7 & 8 \\
\end{tabular} & $8: 910.11$ & \begin{tabular}{|l|l|l|l|}
12 & 13 & 14 & 15 \\
\end{tabular} \\
\hline 1 & 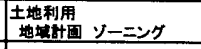 & & & & & & & & & \\
\hline 2 & 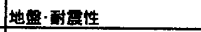 & & & & & & & & & \\
\hline 3 & 空氛の粪 & & & & & & & & & \\
\hline 4 & 水凘源·地关水·水貫污染 & & & & & & 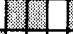 & & & \\
\hline 5 & 蝈害 & & & & & & & & & \\
\hline 6 & 䔔 & & & & & & & & & \\
\hline 7 & 生物学的貫洦 & & & & & & & & & \\
\hline 8 & 光とグレア & & & & & & & & & ex \\
\hline 9 & 自野 & & & & & & & & & . \\
\hline 10 & 슴 & & & & & & & & & \\
\hline 11 & 勗用 & & & & & & & & & \\
\hline 12 & 住宝 & & & & & & & & & \\
\hline 13 & 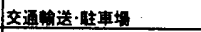 & & & & & & & & & th \\
\hline 14 & 齿行替助暗 & & & & & & & & & \\
\hline 15 , & エネルギー消賞 & & & & & & & & & \\
\hline $16=$ & 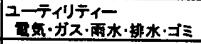 & & & & & & & & & \\
\hline 17 | & 追䁖物 & & & & & & & & & \\
\hline 18: & 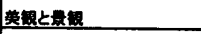 & & & & & & & & & \\
\hline 19 . & 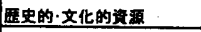 & & & & & & & D & 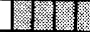 & T. \\
\hline 20 : & 责古学的費洦 & & & & & (1) & & & 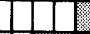 & \\
\hline 21 & 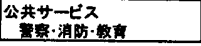 & & & & & & & & & \\
\hline
\end{tabular}

両市に共通する評価項目として、(1) 土地利用 (Land Use)、(3) 空気の質 (Air Quality)、(13) 交通輸送と駐車場 (Transportation and Parking)、(18)美観と景観 (Aesthetic and Visual Quality)、
（19）歴史的 - 文化的資源 (Historic and Cultural Resources) が挙 げられる。これらは CEQAによる環境レヴューにおいて建築に対す る最も基本的な評価項目と捉えられる。（3）空気の質は大気質法 (Air Quality Act)の基準值と照らし合わせての評価を主とし、(13) 交通輸送と駐車場は発生交通量予測に基づく自動車進入路の位置検 討や駐車台数の算定が主な内容である。特に、交通問題の深刻な口 サンゼルス市では交通コンサルタントによる技術編を EIRに加えて 交通量予測を詳細に行っている。これらに対して(1) 土地利用、(18) 美観と景観、(19) 歴史的・文化的資源は、定量的な評価ではないが 建築の方向付けには大きく関る項目である。(1) 土地利用は、特定地 域を対象に土地利用や開発基隻等を定めた特定計画や、コミュニテ イー再開発法に基づく地区の計画(Community Plan)に当該計画が どのように配慮しているか、ゾーニング変更(Rezoning)や条件付用 途許可 (CUP: Conditional Use Permit)等の許認可の必要性やその 理由注 8) を示している。上位計画と建築計画の関係性に関る評価項 目と言える。(18) 美観と景観、(19) 歴史的・文化的資源は、CEQA の標淮評価項目では別項目だが両市ともに相互に関りをもって記述 されている。美観と景観の評価には、街路に対する圧迫感の低減・ 日影検討や光公害の防止・植栽計画等があるものの、周辺の歴史的 · 文化的資源への配慮も景観上重要と捉えられているためである。

これらの評価項目に対して環境影響の程度に応じて、環境影響緩 和策(Mitigation Measures)が検討される。サンフランシスコ市の場 合は建築毎の特徵に応じた評価項目に絞られているため緩和策も具 体的である。しかしロサンゼルス市では評価項目数は多いものの、 建築種別が異なる場合でも技術指針に近い画一的な記載内容が多く、 敷地や建築固有の条件が十分に反映されているとは言えない。

\section{4-3. EIRの代案評価から見た特幑}

代案評価に関しては、米国の CEQA に関する既往調査丈 10) 文 12) で、代案毎の評価が不十分なものが多いとの指摘がなされている。 また、なぜ事業として実現可能性のない代案まで示す必要があるの かという点について争われた訴訟文15)文16) もある。日本の環境アセ スメントでは代案評価は定着しておらず、その役割と課題を建築に ついて具体的に知ることは重要と言える。表-4に両市の代案評価で 検討されている案の種類の比較を示す。

サンフランシスコ市の EIR では既存建物の改修や増築に関係する 代案が多く、これは表-1に示したように歴史的・文化的資源に関る 事例が多いためと考えられる。ロサンゼルス市の場合は「規模の縮 小」・「用途の変更」・「代替敷地」に関する代案が主である。両市と も代案には面積・規模・用途構成を示す表と配置図が示される程度で、 平面図と立面図は無く図面内容は簡易である。評価方法は、各評価 項目について原案と比較しての影響の差異を記述している。評価の まとめ方は、サンフランシスコ市の EIR では代案評価を通して明確 化された解決すべき課題と論点を示し、各代案の事業としての変更 の可能性も説明した事例が多い（表-4の最下段参照)。これに対し てロサンゼルス市の EIR の評価のまとめでは「何もしない案」以外 では 15 例中 11 例が、「規模の縮小案」の環境影響が最も少ないとす る結論で、代案が選択されることを想定した記載が無い。法的には 
計画審議会注 9) 等の意思決定機関が代案を選択する可能性もあるも のの、両市とも建築に対する代案評価の主な目的は、環境への影響 を比較することで計画の環境面での特徴を明瞭にして市民や意思決 定機関の公正な理解を助けることにあると考えられる。サンフラン シスコ市の場合は、そのことがより明瞭に整理されていると言える。

\section{表-4 EIR の代案評価案の種類}

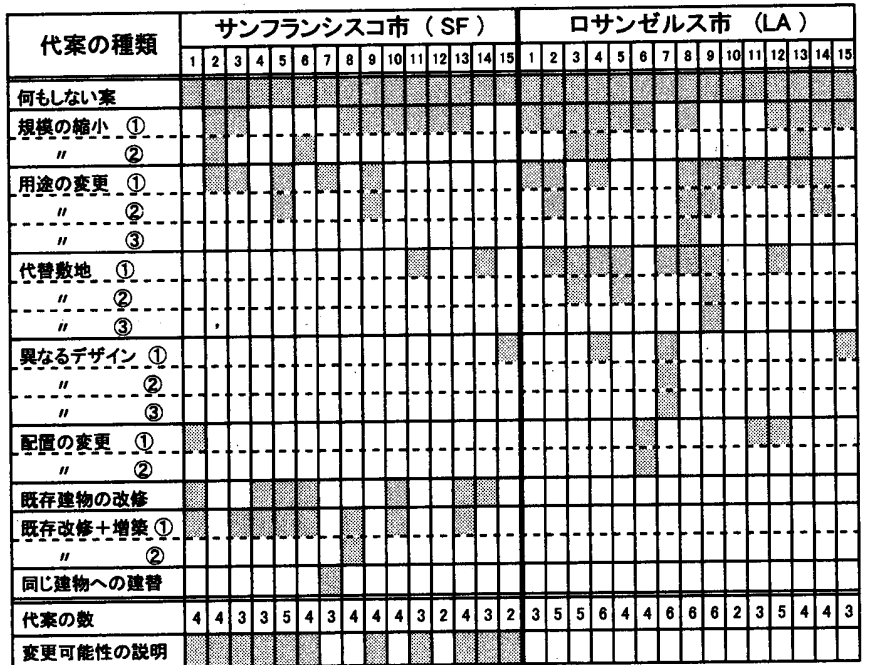

\section{5. 特徽的な $E I R の$ 考察}

\section{5-1. 歴史的・文化的資源の保全と活用に関る EIR}

建築に対する評価の視点は表-3に示したように多様であるが、表 -1 及び表-4 の特徵が示すように建筑の EIR は歴史的・文化的資源 と関りが深い。サンフランシスコ市では特に歴史的・文化的資源に 関る EIR が多く、表-1の 15 事例のうち 13 事例が歴史的・文化的 資源に関る事例である。サンフランシスコ市は市街地に歴史的な街 並みを多く残す都市であることから、環境レヴューがそうした都市 の特徽を反映していることは明らかである。これらのうち 4 事例が 歴史的建築を全て解体して記録保存とする計画、3 事例が歴史的建 筑を耐震補強した上で増築を行う計画、2 事例が歷史的建築を部分 解体して残りと新築建物を利用する計画である。やむを得ず解体す る場合でも事業者負担による記録保存が求められている。

图-1のSF-15の事例は港湾地区の歷史的な 2 階建て倉庫の上部に、 対照的な意匠の事務所を 2 層増築する計画である。代案評価では増 築を行わず耐震補強のみを行う案と、既存部分と同様のレンガ造の 意匠で 2 層分増築する案を検討し、原案では歴史的資源への顕著な

影響は避けられないものの保全活用の一つの方向性であるとして了 解を求める EIR で承認されている。環境レヴューが大規模開発にの み適用されるのではなく、既成市街地の更新の際に失われやすい歴 史的建築の保全と活用に関るものとして実施されている。

両市とも建物の価値の評価において、連邦及び州の歴史的資源登 録と市のランドマーク登録のランク付けを用いている。登録されて いない場合は、それらの公的なサーベイのどのランクに相当するか という主導機関の見解を示している。また EIRには、計画地周辺の 歴史的地区(Historic District)や保全地区(Conservation District)の 良好な環境への配慮や、景観道路(Scenic Highway)からの見え方も 重要な点として扱われている。日本の環境アセスメントでは歴史 的・文化的資源や景観は、評価の根拠が明確でないことから実質的 には重視されていない。しかし CEQA では環境レヴューが景観の形 成と保全にも関るものとして行われている点が特徵的と言える。

\section{5-2. 情報交流を狙いとした EIR の活用}

環境レヴューの公告は全て主導機関の広報やインターネット等で 行われ、申告書は主導機関の事務所のほか公共図書館等で誰でも見 ることが出来る。そうした特徴を活用した事例を考察する。

图-2 に示すSF-11 の事例は、サンフランシスコ市の公営交通機関 (MUNI) が経営多角化のため所有地に民間と共同でホテルを建設 し、そこにあったトロリーバス乗り場の移設も行う計画に対して、 EIR のプロセスによって幅広く市民意見を求めた事例である。

MUNI は市内に多くの土地を所有することから代替敷地案も示し た上で、EIR の結果を基に計画の方向付けを行うことを明示してい る。公聴会注 10) では、現状のバス乗り場の安全性と利便性が低いこ とから反対意見は無く、環境改善に繋がるとして賛同する意見が多 く出された。但しホテルのボリューム構成やクラシカルな外観、歩 道幅等について見直しが必要ではないかとの意見が出され、FEIR (Final EIR：最終環境影響報告書) では、デザインの詳細は計画の 方向付けがなされた段階でさらに検討を行うとする回答が付された。

図-3に示す SF-14 の事例はゴールデンゲートブリッジに近い公園 内の美術館改築に市民参加のワークショップも行われてきた事例で、 さらに広範な市民意見により案を洗練させることを目的に揭げて EIR を行なった。公聴会では、建物を半分埋めてボリュームを抑え たとされる外観が公園内で実際にどのように見えるのかという疑問 や、展望タワーのデザインが良くない等の意見が奇せられた。FEIR では、公園内や周辺道路から見た実際の樹木を入れたモンタージュ 写真を多数追加し、建物とタワーがアイレベルから過半が見えない

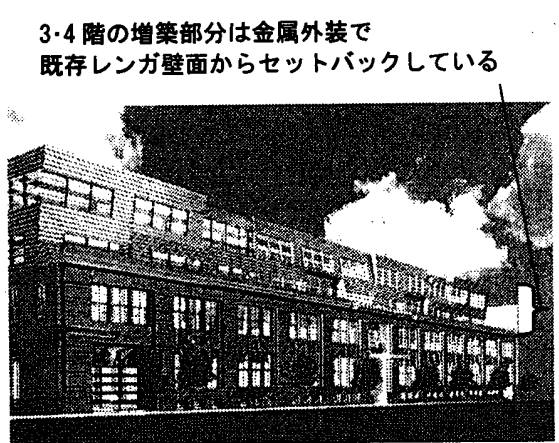

図-1 SF-5 : 歴史的建筑の上階への 増筑の事例 （ロサンゼルス市）

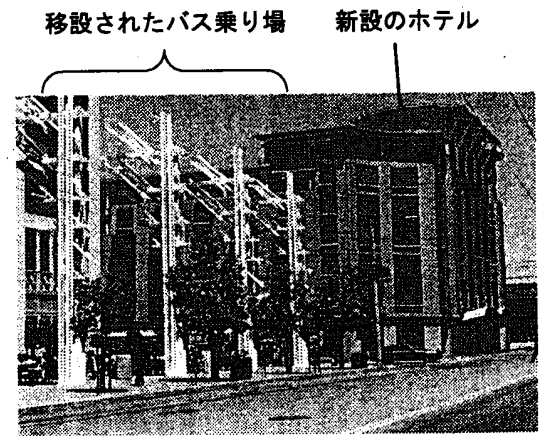

図-2 SF-11：公的事業における 活用の事例 （サンフランシスコ市）

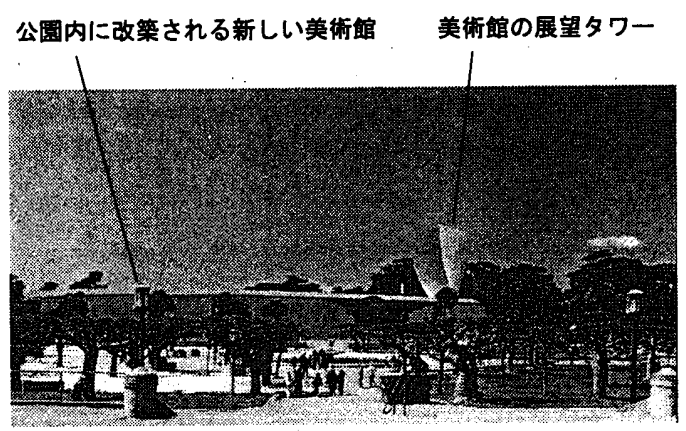

图-3ＳF-14：ワークショップを伴った 活用の事例 （サンフランシスコ市） 
ことを示している。またタワーのデザインはさらに検討を行うとの 回答が付された。EIR は広報誌・インターネット等で公告され、主 導機関の事務所のほか最寄りの図書館や近隣の建物内等で公開され る。そうした特徵を生かし、公園という公共的な場所の建築である ことからワークショップに参加していない周辺住民や公園利用者に も計画を公開し意見を聞く機会を設け、改策計画の認知を図ると共 に新しい美術館への関心の向上を期待している。

これらの事例では環境への顕著な影響を避けるという CEQA の 基本的な目的よりも、環境レヴューによる情報交流の役割に重点が 置かれている。これらはまた、環境レヴューが計画の初期段階で実 施されることの重要性を示している。日本の㻴境アセスメントは事 業の実施と敷地が確定した段階に行われる事業段階アセスメントが 中心であり、このような運用は難しい。CEQA の環境レヴューでは、 計画の方向付けを行う段階で市民意見を建築の計画・設計にフィー ドバックさせる活用が可能と言える。

\section{6. 論争となった建築事例での環境レヴューの役割}

\section{6-1. サンフランシスコ市の保全地区における事例}

本節では表-1の事例の中で特に論争となった計画について、環境 レヴューの特徴を考察する。最初にサンフランシスコ市の保全地区 内の計画で議論となった SF-15 の事例の計画承認までのプロセスを 表-5 に、敷地の現況と計画案の特徵を写真-1に示す。CEQA の環 境レヴューは、歴史的地区での建築行為や登録されたランドマーク 資源の改変等に行われるデザイン審査(Design Review)とは異なり、 公的機関の裁量行為の全般を対象とする環境面の審査である。しか し SF-15 の環境レヴューでは保全地区という地域特性をふまえ、建 築デザインが環境影響の主要な論点となっている。

敷地は、市の都市計画条例 (Planning Code) で定めた 6 つの保 全地区のうち最大の Kearny-Market-Mason-Sutter Conservation District に位置する。地区内には中規模ビルが比較的高密度に集積 し、324 棟の建築物のうち 114 棟の評価が Significant (Category I · II) 、140 棟が Contributory (CategoryIV) にランクされている。 既存建物の多くは基壇を持つ 3 層構成のファサードと正方形に近い 空を持つ。保全地区ガイドラインには強制力は無いが、開発にあた って「小規模のスケール感・明るい色彩・4〜8 階建てを基本とし、 歩行者に快適なスケール感」が望ましいと示している。SF-15 の事 例は既存の 6 階建て商業ビルを解体し10階建てに新筑する建替えで、 既存建物はランドマーク登録のランク外でデザイン審査は不要であ った。ゾーニング変更や CUP のような公告・公聴会等を必要とす
る特別許可 (Special Permit)にも該当していない注8)。しかし主導機 関は、外観が周辺のコンテクストと大きく異なることから、淮備検 討により環境に顕著な影響があると判断して EIR を適用した。この 事例における環境レヴューの役割を模式化したものを図-4に示す。 環境レヴューにより計画が構想段階で明らかとなり、それが歴史的 な佇まいを残寸周辺環境と大きく異なる建築であったことから、近 隣の建物所有者を始め多くの市民から異論が提出された。また EIR の公聴期間に、地元の建築家協会の代表者や芸術系大学教員を含む ランドマーク保全諮問委員会 (LPAB: Landmark Preservation Advisory Board) 注 11) が公開討論会を開催し建築的な価值について

\section{表-5＼cjkstart事例 SF-15 の計画承認までのプロセス}

\section{意思決定機関： サンフランシスコ市計画䈏諹会 (Planning Cormission) 主導機関 : サンフランシスコ市計画局 (Planning Department) 事業主：尼間企業}

2000 年 12 月 23 日 : 市計画局が新聞等で EIR が必要な計画であることを 淮備公告（Notice of Preparation）した。

2001 年 5 月 12 日：DEIR が作成され市計画局が新聞等で公聴会の日付 を公告。計画地の近隣に場所が設けられ DEIR が 38 日間公開され、 申し込みのあった個人・近隣の土地や建物所有者・関倸機関に配布さ れる。DEIR に対する文書による意見表明の受付けが開始される。隣 接する建物所有者から、この計画のデザインは孤立的であり、市のマ スタープランや保全地区に反するとの意見書が出される。地元の建築 設計事務所などから、この計画のデザインは誤った方向性を持ってい るとして反対の意見書が出される。

2001 年 6 月 6 日 : ランドマーク保全䃕問委員会が、この計画に関する公 開討論会を実施する。アメリカ建築家協会(AIA)サンフランシスコ支部 とカリフォルニア・アーツ・クラフツ大学の委員が、この建築が保全 地区に対して斬新な呼応をする提案であるとして支持を表明する。

2001 年 6 月 11 日 : ランドマーク保全諮問委員会は、この建篡は、全体的 な構成や外装材料の点で保全地区と対立的であるものの建物ボリュー ムについては整えられており、この地域の建筑資産の質の高さという 本質的な点に配磨を行い、洗練された新しい表情を加えようとするも のであるとの意見書を提出する。またこの計画の容認が、今後、歴史 的な地区特性に配庿をしなくて良いとのことではないとした。

2001 年 6 月 14 日 : 公聴会が開催される。

2001 年 6 月 17 日: DEIRに対する意見表明が締め切られる。個人 $20 \cdot$ 市 民団体 16 ・企業 14 社さらに報道機関 9 社が反対意見表明を行った。

2001 年 8 月：意見表明に対する回答と DEIR の修正を盛りこみ、FEIR が作成される。FEIR が計画審議会に提出され、計画局で公開される。

2001 年 9 月 : 計画審議会は FEIR が CEQA に基づき一連のプロセスを正 しく行ったものと認め、これを承認寸る。但しこの計画は、建物外観 の構成と材料の点で、保全地区のガイドラインと相容れないものであ り、環境に顕著な影響があり、それは緩和できないものであることが 付記される。

2001 年 12 月 : 事業主が経鼡的な理由からこの事業を凍結する。

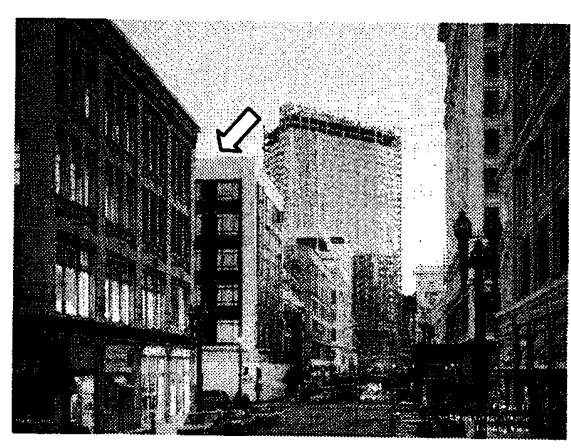

現況写真

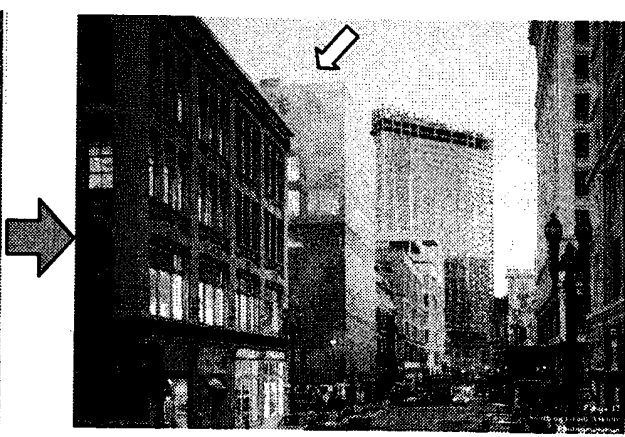

計画案

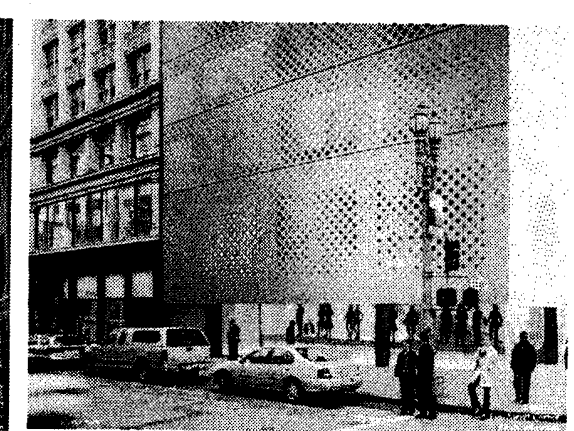

計画案の足元迴り

写真-1 SF-15 : 敷地の現況と計画案のモンタージュ写真（サンフランシスコ市） 


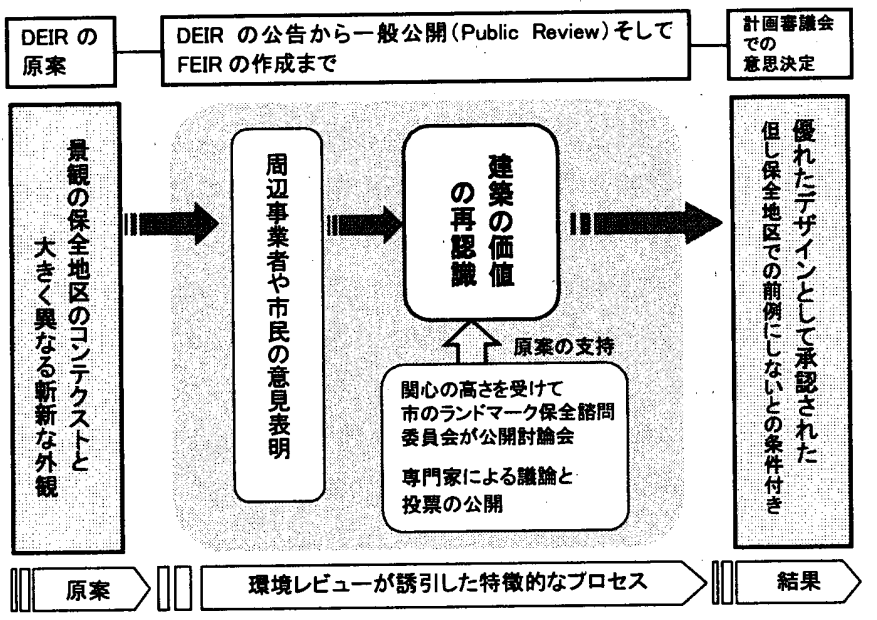

図-4ＳF-15における環境レヴューのプロセスの特徵

議論を行い、委員の投票を経て原案支持の意見書を主導機関に提出 した。主導機関から FEIR の提出を受けた市の計画審議会注 9) は、 意見表明とその回答が記載された FEIR を審查し、手続きを正しく 踏んだものと認めて計画を承認した。但し、この承認を保全地区内 での制限を緩める前例にはしないとの付帯意見を付けている。斬新 な建築の質という分かりにくく暧昧性のある価値を合理的な論拠の そしさを理由に無批判に承認したり、あるいは地区のガイドライン との不整合を理由に画一的修正を求めるのではなく、開かれた場に おいて議論を深め価值を再認識するプロセスを踏ませるところに環 境情報の公開を伴なう環境レヴューの意義が表れている。EIR とな ったことで市民の関心の高さを予測できたからこそ、事業主もモン タージュ写真や外装ディテールを含む詳しい情報を隻備して公開し ている。こうしたプロセスを積み重ねることは、保全地区の環境の 質に対する市民や事業者の認識も樑めることに繋がると言える。

\section{6-2. ロサンゼルス市で建物配置が変更された事例}

次にロサンゼルス市のキャンパス計画事例で、周辺住民とのワー クショップが行われかつ訴訟文 17) も伴った LA-7 の事例の計画承認 までのプロセスを表-6に、当初案の特徴を図-5に、ワークショップ を経てどのように配置計画が変更されたのかを图-6に示す。

LA-7 は大学キャンパスでの図書館・教室棟の新築でゾーニング変 更と CUPも必要で、主導機関は当初は MND (Mitigated Negative Declaration：環境影響緩和措置を伴う影響否定公告）を適用した。 しかし準備公告（Notice of Preparation）の段階で、この計画が周 辺環境にも影響が大きいとの意見が寄せられたため主導機関は EIR

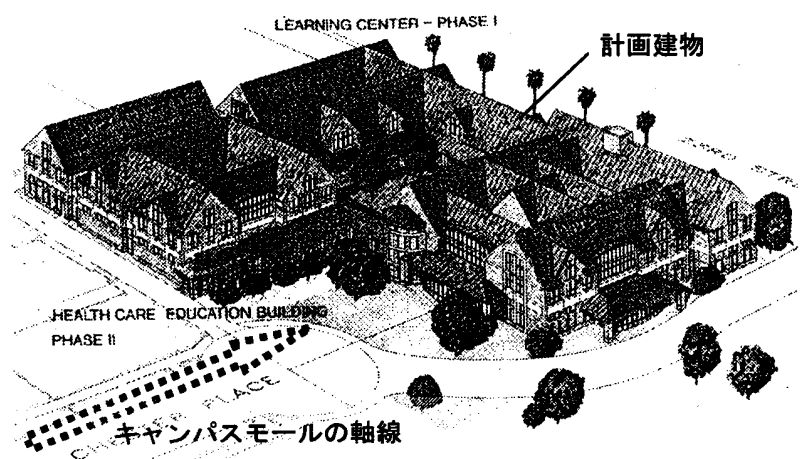

図-5 LA-7：モールのアイストップに建物を配置した当初の 1 娻案
に変更を行った。そして公開された DEIR (Draft EIR：環境影響報 告書案）の計画は、住民も通り抜けでき地域に親しまれてきたキャ ンパスモールの端部に新棟を建設し（図一6)、モールの並木もキャン パス外から見えなくなる計画であった。また環境影響緩和策は、ふ さがれる北側の通りへの圧迫感を減らす為に植栽を行うとの一般的 な内容であった。EIR の公聴期間に周辺環境に顕著な影響を与える との反対意見が出されたが、計画審議会は CEQAの手続きが済んだ ものとして FEIR を承認し、敷地の一部が住居系であったことから

\section{表-6＼cjkstart事例 LA-7 の計画承認までのプロセス}

意思決定機関 : ロサンゼルス市計画賽諲会（Planning Commission 主道機関 : ロサンゼルス市㖕画局（Planning Department） 事業主 : 私立大学

1994 年 5 月 : 計画が申請され、環境レヴューの準備検討（Initial Study）が 行われる。

1994 年 6 月：淮備検討の結果、MND (環境影響緩和措置を伴う影響否定 公告)とされ、30 日間の準備公告（Notice of Preparation）期間に 4 件の意見表明がある。これらの意見から、文化的資源に対して緩和出 来ない影響があることが判明したとして、EIR の作成に変更された。

1995 年 8 月 : 改めて DEIR が作成され、 5 案の代案が検討された。公聴会 が行われ、原案に対し 13 の反対意見表明が提出される。

1995 年 12 月 : FEIRは、手続きを正しく踏んだものとして、市の CEQA に関る意思決定機関である計画審議会で承恝される。

1996 年 3 月 : 公聴会後も多くの意見表明が続いたが、市の計画審議会は、 計画地が住居系地域であったことから必要とされたゾーニング変更と CUP の許可も行い、市議会の土地利用委員会に提出した。

1996 年 4 月 : ゾーニング変更と CUP に対して、建築史家協会・アメリカ 建築家協会ロサンゼルス支部・ノース大学公園コミュニティー委員会 など、個人を含む 25 の反対意見が土地利用委員会に提出された。土 地利用委員会は大学側に意見を踏まえた案を作成し直すよう求め、大 学は反対意見の代表者たちと数回の協議の上、新たな代案を作成した。

1996 年 7 月 : 土地利用委員会は投票によって、その代案を推䔍する旨を決 定した。さらにゾーニング変更と CUP の許可を承認した。

1996 年 9 月 : 住民等がロサンゼルス市を相手どり、元の FEIRをもとにソ 一ニング変更と CUP の許可を行うことは違法との訴えをおこした。

1996 年 5 月 : 法廷は、新しい代案の影響評価を欠いた状態の FEIRをもと にゾーニング変更と CUP の許可を行うことは、CEQA に違反してい るとし SEIR の追加を命じた。そして SEIR で下記の 4 点について考 庿するよう求めた。(1) キャンパスモールから伝統的になされてきた セットバック、(2) 失われる樹木、特に楖子の並木、(3) キャンパス モールの歩行路の景観、(4) 既存の回廊などからの眺め。

1997 年 7 月: 判決に従い新たな代案評価を含むS SEIR が追加作成された。 1998 年 2 月：SEIRが、市の計画審議会で承認された。

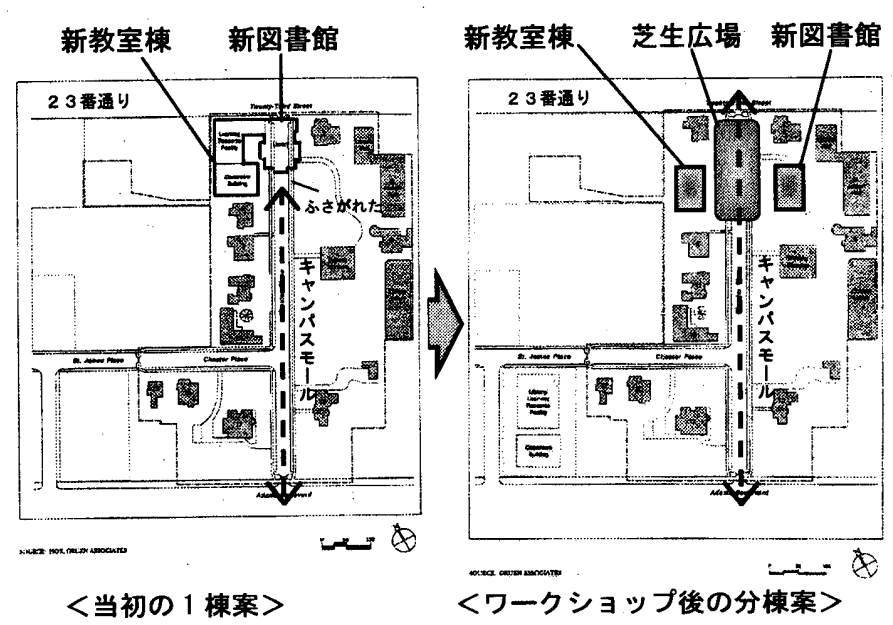

図-6 LA-7 : 配置計画の変更 
必要であったゾーニング変更と CUP の許可も進め市議会の土地利 用委員会 (City Council's Planning and Land Use Committee: PLUM)に提出した。しかし市民等からの反対意見が引き続き寄せら れたことから、PLUM が大学に要請しワークショップが開催され、 建物を図書館棟と教室棟に分棟しモールからの伝統的なセットバッ クを保つ新たな代案が作成された。PLUM もこの案を支持し、ゾー ニング変更と CUP の許可を承認した注8)。しかし住民は最終案につ いても環境影響の評価手続きを踏むべきであると市を訴えて勝訴し、 SEIR (Supplemental EIR : 追加の EIR)が作成されている。 SEIR により計画上重要な点が公にも明確化され、この方針にそって詳細 設計が行われた。原案では建物が配置されていたモールの端部に芝 生広場が設けられ、現在では大学にとって大切なオープンスペース として生かされ、その美しさがインターネット等で広報されている。 この事例における環境レヴューの建築に対する役割を模式化した ものを図-7に示す。環境レヴューがあることにより、並木からセッ トバックして建築が点在する開かれたモールの良さが、計画の初期 段階で再認識された。すなわち敷地環境の持つ価值が関係者以外の 視点の導入により相対化され、より明瞭になった。大学側もこの認 識を共有したことから設計者はそれらを前提に案を練り直し、その 過程でキャンパスの魅力をさらに高めるよう案を発展させた。この 事例は、環境情報の公開と共有により価值の相対化と再認識が図ら れ、それが建築を含む環境の質の向上に具体的に結びつくことを示 している。そこでは、計画・設計にフィードバック可能な段階で環 境レヴューを実施することの重要性が明らかである。

ロサンゼルス市の主導機関によれば、配置計画の修正や訴訟も伴 ったものの環境の質が高められ CEQA の環境レヴューが特に効果 を上げた事例とされる。前節までの考察では、ロサンゼルス市にお いてはサンフランシスコ市ほどの積極的な環境レヴューの活用は認 められなかったが、積極的な市民関与があることで具体的に計画が 改善されることが分かる。

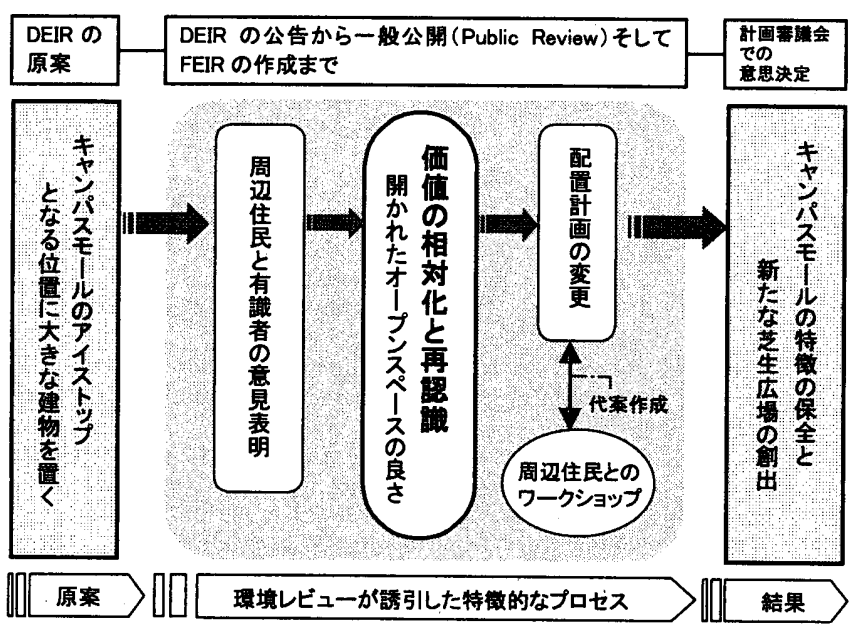

図-7 LA-7における環境しヴューのプロセスの特徵

\section{7. 主導機関による環境しヴューの運用の特徵}

サンフランシスコ市とロサンゼルス市の主導機関である計画局の 環境レヴュー部門に対し、環境レヴューの運用の狙いと問題点の認 識について聴取調査を行った。その概要を表-7に示す。そこからは、 両市とも CEQA の環境レヴューを計画に関る情報を市民が知るた
めの基礎的な仕組みとして位置付けていることが分かる。サンフラ ンシスコ市では建物規模によるのではなく、「ベイアリアなど特徴的 な景観が形成されている地区」・「歴史的な景観の保全を図りたい市 街地」・「生活環境に対する住民意識の高い地区」など、建設地の特 徵を重視して機動的に EIR を適用している。一方、ロサンゼルス市 では大規模な建築に EIR を適用することに加えて、残された数少な い歴史的建築に EIR を適用することを市の方針としている。両市と も歴史的資源の保全に対する効果を環境レヴューに特に期待してい ることが特徽的である。5-1 節の事例は単体の歴史的建築の保全活 用に関るもので、 6 節の 2 事例は歴史のある街並みや景観の特性の 保全に関るものと言える。

\section{表-7 主導機関に対する聴取調查の概要}

\section{サンフランシスコ市計画局}

運用の狙い : EIR はプロジェクトと地域や歴史との関りを市民に知らせる 手段。どの程度まで詳細な内容とするかは建築の種類より立地による。 ベイェリアでは外壁材料と色彩計画も示さなければならない。 EIRに どのように地域資源や周囲との関連性を盛り込むか、そこに主導機関 の考え方が表れる。地域の何を守りたいかということが、だんだんと 明らかになってくる。長期的には環境保全意識の醕成が期待できる。

周辺環境への配慮 : 事業者は噮境レヴューにかかる費用などに不満がある が、CEQA はコミュニティーが事業者や許認可を行う市や郡と話をす る機会を保証している制度である。

EIRにする基準：本来は適用除外である戸建住宅でも、住民の意識が緎細 な地域で CEQA の対象とすることがある。EIRにするかどうかは、立 地によるところが大きい。環境レヴューの集計は行なっていない。

EIRの作成:市が環境コンサルタントに委託し、費用は事業者に請求する。

効果と問題点：地域のコンテクストから離れていても CEQA 自体にはこ れを中止させる実勃力はない。生物学的影響や、危険物・交通・騒音 など定量的な影嚮には CEQA は効力を発揮するが、視覚的な質に関し てはコントロールするカは弱い。EIR の行われた開発に際し市は必ず しも許可を与える必要はないが、有名建築家の設計で周辺睘境亡異質 の建物なども承認されており、そこには CEQA の限界がある。

その他：サンフランシスコ市ではゾーニングや住宅地等の高さ規制を細か く指定しており、計画によってはその変更が必要で都市計画に関る許 可も合わせて必要となる。また歴史的地区に指定されている場所もあ るが、CEQA のプロセスは歴史的地区とは直接に結びついてはいない。

ロサンゼルス市計画局

運用の组い：市民を環境に関することから疎外しない点に意義がある。 周辺環境への配虚 : 公共的な景観や眺めは扱うが、個人だけの眺望は扱わ ない。しかし公聴会では個人的な眺望の意見が述べられることが多い。

EIRにする基準:明確な統計はないが、年間 2000〜2500 件の申請に対し、 約 70\%が CEQA の適用除外行為で、約 30\%に睘境レヴューの蕉備検 討を行う。EIR まで必要とされるのは全申請の1〜2\%で大規模計画 が中心だが、歴史的建築には必ず EIR 適用する。

EIR の作成：事業者が直接、渨境コンサルタントに委託し費用も決める。 効果と問題点：CEQA は設計の細かな内容に関るものではないため、出来 上がる建物が美しいかどうかは別の問題。当市と異なり、サンフラン シスコ市では美しさについても関ろうとしている。

その他：ロサンゼルス市では歴史的建築の多くが既に失われ、僅かに残っ ているものについては是非守りたい。しかし特に指定されたもの以外 は守る有効な方法は無い。CEQA 自体に強制力はないが、EIR を適用 することで着エまでに、市民の意見表明によって事業者が計画を再検 討し守られる可能性がある。市としてはそれを期待している。

\section{8. まとめ}

CEQA は本来、公害防止や生態系保護などの観点から環境に与え る深刻な影響を避けるために環境影響を予測・評価し、それらを公 開した上で意思決定を行う手続きである。しかしサンフランシスコ 市とロサンゼルス市での多様な建築に対する EIR の考察から、建築 計画・設計にとって重要な環境レヴューの役割と、特色ある運用の され方が明らかとなり、その要点は以下のように整理される。 
（1）建築に対する CEQA の環境レヴューは、建築一般図を基本に 外観イメージを加えた内容を基に行われ、意見表明の内容を踏まえ た計画・設計へのフィードバックが可能な段階で行われる。

(2) FEIRには公聴期間の市民等の意見表明とそれに対する回答が 掲載され、市役所や図書館等で誰でも見ることができる。環境レヴ ューは環境情報の共有ツールとして定着している。

（3）建築の裳境レヴューにおける土地利用の評価では、都市のマス タープランや地域毎の計画との関係性が検討され、環境レヴューは 都市・街区・建築を環境面の視点から慗ぐ検討書となっている。

（4）建築の環境レヴューでは、両市共に歴史的・文化的資源の保全 に対する役割を特に期待している。歴史的地区内でなくても、歷史 的建築の解体·改築・再利用等が行われる際にはEIRが適用される。

（5）建築の環境レヴューでは、ランドマーク資源・保全地区・景観 道路と関る評価も重要視され、都市景観の保全に役立てられる。

（6）環境レヴューの情報公開を伴うプロセスの特性を生かし、市民 との情報交流により建築計画の初期段階で重要な多面的な情報収集 を行なうことにも、環境レヴューが活用される。

（7）環境レヴューの運用には、サンフランシスコ市とロサンゼルス 市という対照的な都市の特徴が表れている。CEQA の環境レヴュー は都市的な背景と市民意見を映す情報参加型環境レヴューである。

このように同一の州法に基づく手続き法であるものの、都市の特 徵・地域の特性・建築種別と言った対象の中身に忘じて柔軟に対応 できるところに CEQA の環境レヴューの建築計画・設計に対する重 要な特徴がある。これに対して日本の地方自治体の環境アセスメン トでは対象建築物の規模が大規模なものに限られ、場所固有の価值 を十分に考慮できる仕組みとは言えない。また日本では、アセスメ ント終了前の工事着手制限が行われるのみであるのが一般的注 12) で あるが、CEQA の環境レヴューは図-8に示すように計画初動期の実 施を原則とする。 5 節や 6 節の事例のような計画の方向付けに関る 活用が可能となるのはそのためであり、市民の意見表明による建筑 計画・設計へのフィードバックを可能とし、計画の詳細段階での手 戻りをふせぐことに蒰がる。このことは、情報の共有化を強化する ことにより建築の方向付けに関る計画の構想段階を建築計画・設計 プロセス上も、また社会的にも明確化し比重を高めるものと言え、 建築を含む環境の質を高めることに奇与するものと言える。

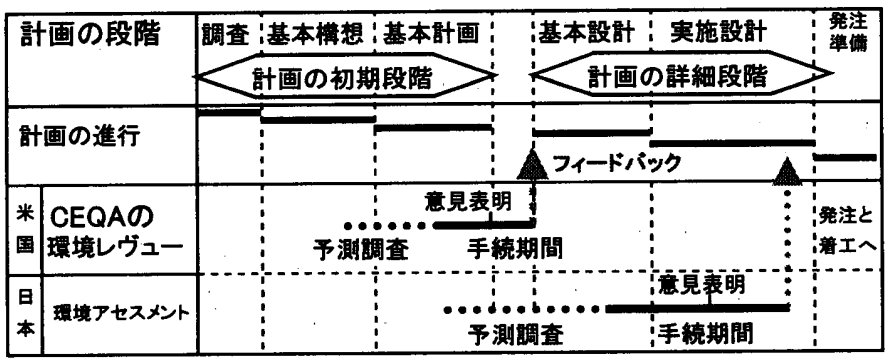

図-8 CEQA の環境レヴューと日本の環境アセスメントの実施時期 ${ }^{\text {注 13) }}$

注

注 1) 日本の環境アセスメシトより広い環境審查の概念として、カリフォルニ 了州の公共図書館や市の担当部局でも Environmental Review という語か 使われ定着していることから、本論ではこれを率境レヴューと訳している。

注 2) 実施例の多い地方自治体として、建築に対する東京都の環境アセスメン トでは高さ $100 \mathrm{~m}$ 以上の高層建築物および 100,000 m²上の大規模建築物、 川崎市は高さ $100 \mathrm{~m}$ 以上かつ $50,000 \mathrm{~m}^{2}$ 以上の高層建築物および $50,000 \mathrm{~m}$ 以上の大規模建築物を主な対象にしている。

注 3) CEQA が適用される裁量行為を下記に示す。建築許可 (Building permit)
は行政行為 (Ministerial Project)であり該当しないが、判例 (Friends of Westwood v. City of Los Angeles, 233 Cal.App.3d 1143,1987)) により、公 的機関の判断を含む場合は裁量行為と見なして適用する場合がある。

(1) 公的機関により直接行われる行為。建設・清掃・造成・改修・地域ゾー ニング・地域の都市基本計画の制定や改正など。

(2) 公的機関により協定・補助金·助成金·貸し付けなどの補助を受ける行為。 (3) 公的機関加の儥借・許可・免許・資格の付与等を受ける行為。

注 4) 適用除外には法令に定めたもの(Ministerial Exemption)とガイドライ ンに類型として示されたもの(Categorical Exemption)があり、建築関連で は戸建住宅・小規模店舗・低所得者住宅・災害復旧用建築等が除かれる。

注 5) 申告書には、環境顕著な影響が無い場合の Negative Declaration (ND)、

顕著な環境影響が有る場合の Environmental Impact Report (EIR) がある。 ND の中でも、環境影響緩和策の実施が必要な場合は Mitigated Negative Declaration (MND) とされる。

注 6) 市立図書館の環境レヴューの検索はプロジェクト名を用いるため全数の 表示はできない。建筑を抽出するための検索キーワードとして Building · Center·Complex のほか, 地名を示す Street·Avenue、建築種別を示す House $\cdot$ Office $\cdot$ School $\cdot$ Hospital $\cdot$ Hotel $\cdot$ Sports $\cdot$ Museum 等を用いて閲覧請 求し、ロサンゼルス市で 15 事例、サンフランシスコ市では 20 事例を得た。 このうちサンフランシスコ市は事例数の多い事務所建築の 5 事例を除き、 两市同数の 15 事例について DEIR 及び FEIR を複写した。

注 7) 調查は 2002 年 8 月に実施した。

注 8) CEQA は環境面の観点から実施されるが、ゾーニング変更や CUP 等を 伴う場合にはそうした都市計画の許可の手続きに合わせて行う。

注 9) Planning Committee : 両市の環境レヴューでは、CEQA が定めた意思 決定機関に位置付けられ、投票で信任された審議委員により構成される。

注 10) 公聴会は CEQA では義務付けられておらず主導機関の判断によるが 表-1の全事例で、日本での縦覧に相当する公聴期間 (Public Review Period) の間に実施されている。公聴期間は 45 日間または 30 日間が多い。

注 11) LPAB : 市の計画局の榙問機關で学識経験者・市民等から構成される。 歴史地区の建築やランドマーク資源の改変等に対してはその適合性承認審 查 (Certificate of Appropriateness) にLPAB の審査も伴うが、SF-15 は 荄当していない。しかし CEQA は主導機関に対し申告書の関係機関への送 付を求めており、本事例ではLPABは意見書という形で意見表明を行った。

注 12) 東京都においては 2002 年から都の行う公共事業に関しては計画段階ア セスメントが行われている。

注 13) 手続期間は、CEQA の環境レヴューでは DEIR 作成から FEIR 承認ま で、日本の環境アセスメントでは環境影響評価書案の作成から環境影響評 価書の審議会承認までの実施期間の概念を示した。

\section{参考文献}

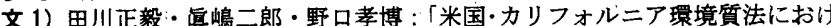
る判例から見た 環境情報の公開をふまえた噮境レヴューの建築計画にお ける意味」日本建築学会計画系論文報告集、第 561 号、pp. 151 158、2002. 11

文 2) 田川正毅・冝嶋二郎・野口孝博 :「米国・カリフォルニア環境質法に基つ く、カリフォルニア大学リバーサイド校での敷地コンテクストを重視した 環境レヴューの実践」日本建築学会技術報告集第 17 号、pp. 349〜354、 2003. 6

文 3) CEQAに関する州政府ホームページ : http://ceres.ca.gov/ceqa/

文 4）環境庁環境アセスメント研究会監修（財）地球・人間環境フォーラム： 「世界の環境アセスメント」、ぎょうせい、1996

文 5) 秋本福雄 :「公共と民間の協議による都市開発に関する考察 一アメリカ における Negotiate developments $の$ 類型とプロセスー」日本都市計画学会 学術研究論文集、No. 28、pp. 289〜294、1993.11

秋本福雄 :「公共と民間の協議による都市開発の計画と実施手段とプロセス に関する考察一カリフォルニア州の事例一」日本都市計画学会学術研究論 文集、No. 30、pp. 421 426、1995. 11

秋本福雄 :「パートナーシップによるまちづくり 行政・企業・市民・アメ リカの経験小、学芸出版社、pp. 179 184、1999

文 6) ウィリアム・フルトン:「カリフォルニアのまちづくり 都市計画の最先 端地域から学ぶ」花木啓祐+藤井康幸訳、技報堂出版、pp. 147 172、1994

文 7) 西村幸夫十まちな子研究会編著 :「都市の風景計画 欧米の景観コント ロール 手法と実際」、学芸出版社、pp. 135 141、2000

文 8) Michael H. Remy, Tina A. Thomas, James G. Moose, Whitman F. Manley : 「Guide to California Environmental Quality Act (Tenth edition)」, Solano Book Press, 1999

文 9) Ronald E. Bass, Albert I. Herson, Kenneth M. Bogdan: 「CEQA Deskbook - A Step-by-step Guide on how to comply with the California Environmental Quality Act $\rfloor$ S Solano Book Press, 2001

女 10) Association of Bay Area Governments CEQA Study,

Association of Bay Area Governments (ABAG), 1991

文 11 ) California Planning Department Survey, Professor Robert Olshansky of the University of Illinois, 1992

文 12) California Policy Seminar CEQA Study, Professor John Landis of U.C. Berkeley, 1995

文 13) Environmental Impact Assessment Review, Elsevier Inc. 1980-2003 文 14) Land Use \& Environmental Law Review, Thompson West Inc. $1980-2003$

文 15) Citizens of Goleta Valley v. Board of Supervisors : 197 Cal.App.3d 1167,1988

文 16) Mann v. Community Redevelopment Agency of the City of Hawthorne : 233 Cal.App.3d 1143, 1991

文 17) Save Chester Place v. City of Los angels : No.BS041368, 1996 